Linguistik Terapan 14 (1) (2017): 27-34

Jurnal Linguistik Terapan Pascasarjana

Available online

http://jurnal.unimed.ac.id/2016/index.php/JLT-Unimed

\title{
CODE SWITCHING IN SARAH SECHAN TALK SHOW PROGRAM ON NET TV
}

\section{EKA REJEKI MAHA}

\section{Zainuddin}

I Wy Dirgeyasa

Linguistik Terapan bahasa Inggris Universitas Negeri Medan

Diterima Februari 2017; Disetujui April 2017; Dipublikasikan Juni 2017

\begin{abstract}
This study was aimed at examining code switching in Sarah Sechan talk show program on NET TV. The objectives of the study are to find out the types of code switching occurring in the talk show, the process of code switching, and the reasons for code switching in the talk show. This research was conducted by using qualitative descriptive design. The source of data was Sarah Sechan talk show. There were five episodes of Sarah Sechan talk show as the data of this study. The technique of data collection was documentary technique and the instrument of data collection was recorder. The technique of data analysis was interactive model by Miles, Huberman and Saldana (2014). The findings showed that all types of code switching occurred in Sarah Sechan talk show with different proportion. The most dominant type occurring in the talk show is intra sentential switchingThe processes of code switching occurred in Sarah Sechan talk show are insertion, alternation and congruent lexicalization. Reasons for using code switching were expressing solidarity, ethnic identity marker, changing the topic, switching for affective meaning, and emphasizing the meaning.
\end{abstract}

Keywords: Code Switching, Types of Code Switching, Processes of Code Switching, Reasons for Code Switching, Talk Show

How to Cite: Maha, Eka Rejeki (2017).

Code Switching in Sarah Sechan Talk Show Program on TV Net. Jurnal Linguistik Terapan 
Pascasarjana Unimed, 14 (1): 27-34

ISSN 2407-7410

\section{INTRODUCTION}

Sociolinguistics is one of linguistic branches that can be analyzed from various point of view. Sociolinguistics is a term including the aspects of linguistics applied toward the connections between language and society and the way it is used in different social situations. It ranges from the study of the wide variety of dialects across a given region down to the analysis between the way men and women speak one to another. Sociolinguistics often shows the language that describes the age, sex, and social class of the speaker. It codes the social function of a language. (Baker, 2010).

Sometimes people want to communicate only to certain people or community they belong to. To avoid the other community or people interfering their communication, they may try to exclude those people by using the language that not everybody knows/masters. When people want to talk each other, they have to choose a particular code to express their feeling. According to Stockwell (2002), a code is a symbol of nationalism that is used by people to speak or communicate in a particular language, or dialect, or register, or accent, or style on different occasions and for different purposes. The people usually choose different codes in different situation.

They may choose a particular code or variety because it makes them easier discuss a particular topic, regardless where they are speaking. When talking about work or school at home, for instance, they may use the language that related to those fields rather than the language used in daily language communication at home.

Put simply, when choosing code, they sometimes switch their language when they communicate to the others. It is called as code switching. Poplack (1980) states that code-switching is the alternation of two languages within a single discourse, sentence or constituent. Code switching was considered as sociolinguistic phenomenon, a linguistic product of language contact, determined in various ways by the social circumstances in which it occurs (Chloros 2009). Code switching is a very important aspect of bilingualism, and is considered a natural occurrence when two bilingual speakers engage in discourse. Mostly, such speakers are not consciously aware that they are code switching. Nonetheless, it serves an important social function. Whenever there is more than one language spoken in a community, its population code-switches for effective and impressive communication.

Code-switching is a common phenomenon in multilingual and bilingual societies. Indonesian is also among those countries, where multilingualism and bilingualism exist. There are number of indigenous languages which are spoken in Indonesia. Bahasa Indonesia, is used as a national "lingua franca" to provide the many different people of Indonesia with a common language in which to communicate with each other. The influence of English as a foreign language is quite conspicuous. Majority of the educated class is almost bilingual in formal as well informal interaction. Code- 
switching from Indonesian to English and vice versa is extensively in practice. And the most authentic and obvious examples are TV talk shows. In almost all the Indonesian TV channels code-switching of Indonesian and English is frequently exercised. It is bilingualism of Indonesian and English which is commonly noticed in the TV talk shows of Indonesian TV channels.

Code switching in television talk shows gives many positive impacts on viewers. According to Abullah and Buriro (2011) codes switching in the TV talk shows are used to help to understand the message easily, to enhance the effectiveness of communication, to have a better effect on the audience, to shorten vocabulary in one language, and to show him or herself educated. It means that if the guest or the host in the television talk shows does not use the code switching it will be hard to deliver the message easily; communication will not be effective and the last it cannot be used to get a better effect on the audience.

Net TV is one of the latest private television stations which also broadcast various talk shows. It broadcasts some talk show programs such as Ini Talk Show, Tonight Show, Sarah Sechan, etc. Sarah Sechan is a talk show program which is running from Monday up to Friday at 9 a.m. According to Wieten et.al (2000) There are three basic subgenres of talk show; they are political talk show, celebrity talk show, and participatory talk show. Sarah Sechan talk show is classified into the subgenre of celebrity talk show because this talk show is built around interviews with figures from the world of fashion, sport, the media, and show business. This talk show emphasizes on establishing intimacy and approachability between the host, the guests and the audience. The talk show is chosen to be the source of data in this study due to some reasons. First, the talk show is familiar and always discusses hot issues related to personal life, music and achievements. It is proved by winning KPI Awards 2014 and Yahoo Celebrity Awards 2014. Second, the guests who are invited in talk show are famous and professional in their field. Third, talk show is mostly viewed by society in Indonesia. Last, the host and the guests who are invited to this talk show often to do the code switching from Bahasa Indonesia to English or vice versa.

In Sarah Sechan talk show program on Net TV, both host and the guests switch the code when discussing the topics. Generally, the host and the guests code switch the language to express their felling. As the focusing analysis in this research, the writer presented some interactions as follows:

SS Oh, hebat banget sih. She's like so busyyakan? How would you do all this thing? Sibuk sekali soalnya. Apa aja kamu kerjakan. Gimana gitu bagi waktunya ya dengan kuliah gak takut jadi masalah besar gitu?

MA Iyasih jadi waktu itu aku kayak mikir wah it's gonna clash gitu. Tapi mereka bilang trust me, this is important ini penting banget. Trus baru malamnya aku dikasi tau kalo aku bakal ketemu sama Prime Minister bahwa you will host him.

SS Jadi kamu gak nervous? 
MA Jadi aku awalnya I'm not really nervous awalnya. Tapi waktu nervous itu waktu before taking him to the café aku itu ngeliat ada lima mobil dan aku sendiri harus nyambut dia itu bener-bener chill banget. I am thrilled at that time

SS Riweh gitu ya ada apa ini ada apa kok rame-rame. Tapi kalo aku liat kamu you don't really get nervous easily. Apasih rahasianya? How do you overcome masalah-masalah itu?

MA Hem mungkin karna aku udah sering tampil dari kecil ikut musical, teater setiap tahunnya jadi kek apasih kayak akunya I find comfort in it. Aku udah nyaman aja

SS Oh jadi itu udah kayak it's your safe place, your comfort zone, right? Cakep banget ya. Saya tuh ngomong kebaratan gitu biar kayak orang pinter, I wanna be like her. Maudy kan pinter bisa kuliah di Oxford.

(episode:Maudy Ayunda Dampingi PM Inggris)

In fact, the discourse between host and guests above shows that it is unavoidable to use only one language when someone does interaction with others. The intensity of switching languages will be also greater in a country where bilingual or multilingual occurs, including Indonesia as the preliminary above.In the data above,the guest said "Iyasih jadi waktu itu aku kayak mikir wah it's really gonna clash gitu". That utterance which was said by the guest was classified into the type of intrasentential code switching.In intrasentential code switching, the shift is done in the middle of a sentence, with no interruptions, hesitations or pauses indicating a shift and the speaker is usually unaware of the shift (Hoffman,1991). The host here is unaware when she switched her language into another language. In Sarah Sechan talk show on NET TV code switching also plays a significant role in disguising an idea that can be shown. The guest switched her language into English (it's really gonna clash) in order to disguise an idea that she thought it will be big problem between her study and her carrier.Code switching is also used to show the feeling of the speaker(Holmes 2001). The guest here code switched her language into English when she wanted to show her feeling in the sentence "I am thrilled at that time". That sentence shows how speaker's feeling was. Furthermore, Abdullah \&Burriro( 2011) also agreed that code switching is used by the host and guest' to show him or herself educated. It is shown by the sentence "Saya tuh ngomong kebaratan gitu biar kayak orang pinter, I wanna be like her. Maudy kan pinter bisa kuliah di Oxford." It is clear that code switching is used by host to show that she is educated and smart to the people who watched this talk show.

In regarding to the explanations above, code switching is considered important to be researched. This study was intended to describe the types, processes, and reasons for code switching in Sarah Sechan Talk Show Program on NET TV.

In this study actually the researcher would like to investigate the types of code switching used by host and guests in Sarah SechanTalk Show Program on Net TV, to describe the process of those 
types of code switching used by host and guests in Sarah Sechan Talk Show Program on Net TV and to give the reasons why the host and the guest used those types of code switching in Sarah Sechan Talk Show Program on Net TV.

\section{RESEARCH METHODOLOGY}

The research was conducted by using qualitative descriptive design. Patton (2002) defined qualitative research as attempting to understand the unique interactions in a particular situation. The purpose of understanding is not necessarily to predict what might occur, but rather to understand in depth the characteristics of the situation and the meaning brought by participants and what is happening to them at the moment. Bogdan \& Biklen (1992) state that qualitative is descriptive. It means that the data are collected in the form of words rather than number. Descriptive qualitative design tries to analyze the data with all of their richness as closely as possible to the form in which they are recorded and transcribed, and the written result of the research contains quotation from the data to illustrate and substantiate the presentation.

The data of this study were the sentences that contained code switching within the level of phrases, clauses or sentences which were found in utterances between the host and guests in Sarah Sechan talk show program on Net TV. The source of data was Sarah Sechan talk show. The technique of data collection applies in this study wasdocumentary technique and the instrument of data collection was recorder. The data were collected by downloading the video Sarah Sechan talk show through official channel. Then, she transcribed each of the host and the guests' utterances while they talked, commented, interacted and responded each other. The data were analyzed based on interactive model proposed by Miles, Huberman, and Saldana (2014: 33). They elaborated several steps of analyzing the data: they are (1) Data Collection, (2) data condensation, (3) data display, and (4) data Verification/conclusion

\section{FINDINGS}

The findings are described as the following: 1) It is found that all types of code switching occurred in Sarah Sechan Talk Show Program on NET TV. They are tag switching, intrasentential switching, and intersentential switching. Dominantly, from the data, the researcher found the intrasentential code switching in this research between host and guests in the talk show. Both host and guests tended to switch their language within a clause or sentence. 2) It is found that all processes of code switching occurred in Sarah Sechan Talk Show Program on NET TV. They are insertion, alternation and congruent lexicalization. Dominantly, from the data, the researcher found the insertion in this research between host and guests in the talk show. 3) It is found that five reasons for code switching occurred in Sarah Sechan Talk Show Program on NET TV. They are expressing solidarity, ethnic marker, changing the topic, switching for affective function and emphasizing the meaning. To 
quote somebody as the reason for using code switching cannot be found in this research. Dominantly, from the data, the researcher found the switching for affective function used between the host and the guests. It is because they want to express their emotional feeling to people who watched the talk show.

\section{DISCUSSION}

After having analysis the data, there are some points as the important ones to be discussed in this study. In this research, there are tag switching, intrasentential switching and intersentential switching between host and guests in talk show. It is supported the theory of Hoffman (1991) that states there are three types of code switching, they are tag switching, intrasentential switching and inter sentential switching. Dominantly, from the data of this research is the intrasentential code switching between host and guests in talk show because both of the host and guests switch language within a sentence or a clause boundary.

From the relevance study, Azlan (2013) conducted a study about The Role of Code Switching as a Communicative Tool in an ESL Teacher Education Classroom. The findings show that inter sentential switching is the most dominant type to be used and the most dominant reason is to emphasize the point. His findings are different from this study. In this study, the researcher found that intra sentential switching is the most dominant type used by the host and guests in the talk show. The most dominant reason in this study, was not also to emphasize point but to get affective meaning. The studies have the different findings because they were conducted in the contexts. The findings from Azlan (2013) was found in ESL classroom meanwhile, the findings in this study are found in the talk show.

In additional, this study also found that there are three processes of code switching occurred in Sarah Sechan talk show. They are insertion, alternation and congruent lexicalization. The findings of this research was similar to Muysken (2000) that categorizes three different code switching consider as the processes of making code switching. Insertion is a process akin to borrowing but where elements longer that a single word may be inserted. Alternation occurs when there is compatibility of the two grammars, or at least equivalence at the points at the switch occurs. Congruent lexicalization occurs in which the languages share grammatical structure but the vocabulary comes from two or more languages. Dominantly, from the data of this research is Insertion. The host and the guests inserted the English language into the overall structure of Indonesian language because they may have limited abilities in Indonesian language so they inserted English language to deliver the meaning that they want to convey.

And the third point that can be discussed from the findings were the reasons of code switching used by host and guest in Sarah Sechan Talk Show Program on NET TV. There are five reasons for using code switching. They are, expressing solidarity, ethnic marker, changing the topic, 
switching for affective function and emphasizing the meaning. On the other hand, Holmes(2001) gives six reasons why people tend to code switch between the languages in the society they are expressing solidarity, ethnic marker, changing the topic, to quote someone, switching for affective function and emphasizing the meaning.

Based on the previous study Muthusamy (2013) who had conducted a study about Communicative functions and reasons for code switching: A Malaysian perspective found that there are many reasons why code switching takes place in particular social contexts. The ability of the interlocutors who are able to speak more than one language fluently plays an important role during their interaction. The study has shown that the undergraduates have emphasized that habitual expression which is related to psychological aspect of behavior as their main reason for code switching. Besides that, lack of register competence is also another contributing factor for code switching. It was different with the result in this study since the main reasons for host and guests to code switch the language is to get affective meaning. Muthusamy (2013) found it in natural conversation while this study done in Sarah Sechan as a talk show. These different contexts apparently create different criteria too. It can be concluded that different context result different reasons for using code switching.

Furthermore, the findings of this study is also different from Mehar (2014) that investigates about social aspects of Code switching in Pakistani Television advertisement. Although both of these studies analyzed the code switching occurred in television but they have different findings. Mehar (2014) stated that people tend to code switch to indicate their affinity for language prestige which is considered an emblem of socio economic strength and sophistication in television advertisement. Since the goal of the advertisement is to persuade it is useful to use the language that showed the superiority and prestige. It was different with the result of this study that showed host and guests tend to code switch to get affective function in television talk show. This talk show contains the casual information or news which can be enjoyed as wide selection of day time talk show. Thus, code switching was used by the host and also the guests to express their feeling so that the people who watched the talk show can enjoy the content of the talk show.

\section{CONCLUSIONS}

The conclusions can be drawn that 1) The host and the guests used all types of code switching in Sarah Sechan talk show Program on NET TV. They are tag switching, intrasentential switching and intersentential switching. The intra sentential switching had the highest frequency used by the host ad the guests in Sarah Sechan talk show. 2) All processes code switching occurred in Sarah Sechan talk show Program on NET TV. They are insertion, alternation and congruent lexicalization. Insertion is the most dominant process in the talk show. 3) The reasons for using code switching were to express 
solidarity, to showethnicidentitymaker, to change the topic, to get affective meaning, and to emphasize the meaning. Getting affective meaning was frequently used by the host and the guests in order to express their feeling during the talk show. Further, It is suggested to other researchers who concern to the study of code switching to elaborate three types of code switching found in this study in other context

\section{REFERENCES}

Abdullah, M and Buriro,G. (2011). Code switching in television talk show and its impact on viewers. Retrieved on July 15 2016. athttp://www.arabguide.net/t2k/wsu/docs/2010-2-CodeSwitching.pdf

Azlan, NikMastura. (2013). The Role of Code Switching as a Communicative Tool in an ESL Teacher Education Classroom. Retrieved on July $13^{\text {th }}$ 2017.Elsevier Ltd.

Baker,P. (2010). Sociolinguistics and Corpus Linguistics. Edinburg: Edinburg University Press

Bogdan, R.C. \& Biklen, S. K. (1992). Qualitative Research for Education. Boston: Allyn and Bacon.

Hoffman, C. (1991). An Introduction to Bilingualism. London: Longman.

Holmes, J. (2000). An Introduction to Sociolinguistics. England: Pearson Education.

Miles, Huberman, \& Saldana. (2014). Qualitative Data Analysis. Thousand Oaks: Sage.

Muysken, P. (2000). Bilingual Speech: A Typology of Code Mixing. Cambridge: Cambridge University Press

Poplack, S. (1980). Sometimes I'll start a sentence in Spanish Y TERMINO EN ESPANOL: toward a typology of code-switching. United Kingdom: Routledge

Patton, M. Q. (2002). Qualitative Research and Evaluation Methods. Thousand oaks, CA: Sage.

Stockwell, P. (2002). Sociolinguistics: A Resource Book for Students. London: Routledge

Wieten, Jan et al. (2000). Television across Europe: A Comparative Introduction. London: SAGE

Publication Ltd. 